\title{
Influence of Red Blood Cell Distribution Width on Long-term Prognosis of Percutaneous Coronary Intervention for Patients with Non-ST-Segment Elevation Acute Coronary Syndrome
}

\author{
X-M Liu, C-S Ma, X-H Liu, J-Zeng Dong, X Du, Y Zhang, Q Lv, J-P Kang
}

\begin{abstract}
Objective: The aim of this study was to investigate the influence of red blood cell distribution width $(R D W)$ on the long-term prognosis of percutaneous coronary intervention (PCI) for patients with non-ST-segment elevation acute coronary syndrome (NSTEACS).

Methods: Two thousand one hundred and eighty-five NSTEACS cases with coronary artery disease and preoperative record of $R D W$ who under went elective PCI treatment from July 2009 to September 2011 were selected. According to preoperative RDW levels, the patients were divided into two groups. One thousand one hundred and seventy cases belonged to the $R D W<12.2$ group, 1015 cases belonged to $R D W \geq 12.2$ group. The clinical characteristics and the incidence of postoperative mortality in the two groups were compared. There was a follow-up period of 540 days.

Results: Patients in the $R D W \geq 12.2$ group were females with characteristics such as: hypertension, history of cerebrovascular disease, hospital use of $\beta$-blockers and high body mass index (BMI) at admission, low haemoglobin and total cholesterol levels.

The postoperative mortality of $R D W \geq 12.2$ group $(2.7 \% \mathrm{vs} 1.0 \%, \mathrm{p}=0.004)$ was significantly higher than that of $R D W<12.2$ group. In multivariate Cox regression analysis, after adjustment for other factors, $R D W \geq 12.2$ in the patients with postoperative PCI was an independent predictive factor for mortality (HR 2.171, 95\% CI 1.007, 4.680, $\mathrm{p}=0.048$ ).

Conclusion: High RDW in patients with postoperative PCI was an independent predictive factor for mortality.
\end{abstract}

Keywords: Non-ST-segment elevation acute coronary syndrome, prognosis, red cell distribution width (RDW)

\section{Influencia de la Amplitud de la Distribución de los Eritrocitos en el Pronóstico a Largo Plazo de la Intervención Coronaria Percutánea en Pacientes con Síndrome Coronario Agudo sin Elevación del Segmento ST}

\author{
X-M Liu, C-S Ma, X-H Liu, J-Zeng Dong, X Du, Y Zhang, Q Lv, J-P Kang
}

\begin{abstract}
RESUMEN
Objetivo: El objetivo de este estudio fue investigar la influencia de la amplitud de la distribución eritrocitaria (ADE, o ADR, amplitud de la distribución de los glóbulos rojos) en el pronóstico a largo plazo de la intervención coronaria percutánea (ICP) en pacientes con síndrome coronario agudo sin elevación del segmento ST (SCASEST).

Métodos: Se seleccionaron dos mil ciento ochenta y cinco casos $(2,185)$ de SCASEST con enfermedad arterial coronaria y registro preoperatorio de ADE que aceptaron el tratamiento electivo de ICP de julio de 2009 a septiembre de 2011. De acuerdo con los niveles preoperatorios de ADE, los pacientes fueron divididos en dos grupos. Mil ciento setenta casos pasaron a formar parte del grupo ADE $<12.2$, mientras que 1015 casos formaron parte del grupo $A D E \geq 12.2$. Se compararon las características clínicas y la incidencia de mortalidad postoperatoria en ambos grupos. Hubo un período de seguimiento de 540 dias.
\end{abstract}

From: Department of Cardiology, Beijing Anzhen Hospital, Capital Medical University, Anzhen Road, Chaoyang District, Beijing 100029, China.
Correspondence: Dr C-S Ma, Department of Cardiology, Beijing Anzhen Hospital, Capital Medical University, Anzhen Road, ChaoYang District, Beijing 100029, China. Fax: +86 010 64456078, email: changshengmacn@163.com 
Resultados: Los pacientes en el grupo ADE $\geq 12.2$ eran mujeres con características tales como hipertensión, historia de enfermedad cerebrovascular, aplicación hospitalaria de $\beta$-bloqueadores, alto indice de masa corporal (IMC) al momento del ingreso, bajos niveles de hemoglobina y niveles de colesterol total.

La mortalidad postoperatoria del grupo ADE $\geq 12.2(2.7 \% \mathrm{vs} 1.0 \%, p=0.004)$ fue significativamente mayor que la del grupo $A D E<12.2$. En el análisis de regresión de Cox multivariante, después del ajuste de otros factores, la $A D E \geq 12.2$ de los pacientes con ICP postoperatorio devino un factor predictivo independiente de mortalidad (HR 2.171, IC 95\% 1.007, 4.680, $p=0.048$ ).

Conclusión: La ADE alta en pacientes con ICP postoperatorio fue un factor predictivo independiente en relación con la mortalidad.

Palabras claves: Síndrome coronario agudo sin elevación del segmento ST, amplitud de la distribución eritrocitaria, pronóstico

West Indian Med J 2017; 66 (1): 37

\section{INTRODUCTION}

Red blood cell distribution width (RDW) can reflect significantly various sizes of red blood cell volume when the mean corpuscular volume was still in the normal range. Therefore, RDW can reflect in vivo environmental changes and red blood cell proliferation changes sooner than haemoglobin and mean corpuscular volume. Red blood cell distribution width was used for clinical diagnosis and differential diagnosis of anaemia (1). Studies have shown that increased RDW also could be used as a reflection of inflammation index (2-5).

Recent studies have shown that increased RDW was not only a predictor of a poor prognosis in heart failure $(6,7)$, coronary artery disease (8-10) and pulmonary hypertension (11, 12) but also had predictive value for prognosis of patients with stable coronary artery disease undergoing percutaneous coronary intervention $[\mathrm{PCI}](13,14)$. Currently, there are no studies about the impact of elevated RDW on the prognosis for NSTEACS patients undergoing PCI. This study aimed to investigate the effects of RDW on prognosis by analysing the clinical data and follow-up of NSTEACS patients undergoing PCI.

\section{SUBJECTS AND METHODS}

\section{Subjects}

In this study, 2185 NSTEACS cases with coronary artery disease and preoperative record of RDW who had elective PCI treatment from July 2009 to September 2011, were selected. The demographic data, clinical features, laboratory tests, medications, coronary artery disease and revascularization information during hospitalization were recorded, and the clinic or telephone follow-ups were documented. According to the median of preoperative RDW (12.2\%), the patients were divided into two groups (RDW $<12.2$ group included 1170 cases, $R D W \geq 12.2$ group included 1015 patients). The clinical characteristics and the incidence of postoperative mortality of the two groups were compared. This study was conducted in accordance with the Declaration of Helsinki. This study was conducted with approval from the Ethics Committee of Capital Medical University. Written informed consent was obtained from all participants.

\section{Data processing}

Raw data related to the research topic was collected from standard hospital medical history by researchers. The laboratory tests and echocardiographic data were the data on admission to hospital before the interventional procedure. The follow-up and input of all data were completed by cardiologists. The telephone follow-up was performed according to a pre-designed questionnaire, the follow-up data were filled into a unified form, then entered into the computer database.

\section{Statistical analysis}

Measurement data were expressed as a mean \pm standard deviation. The measurement data between the two groups were compared using $t$-test. Enumeration data was compared using a Chi-squared test. The relevant factors affecting the overall mortality were statistically analysed by Cox regression equation. Cox regression analysis was performed to calculate the relative risk (HR) of all relevant factors and 95\% confidence intervals (95\% CI) using two-sided test. $p<0.05$ was considered to be statistically significant. All data analysis was processed using SPSS13.0 statistical software.

\section{RESULTS}

\section{General information}

All enrolled 2185 patients comprised of 1170 cases with RDW $<12.2$ and 1015 patients with $\mathrm{RDW} \geq 12.2$. The average follow-up duration was 540 days; the follow-up rate was $93.1 \%$. Compared with the patients in the $\mathrm{RDW}<12.2$ group, the proportion of female patients in the $\mathrm{RDW} \geq 12.2$ group was large, and more patients had combination of hypertension and history of cerebrovascular disease, and the body mass index (BMI) was high at admission, the haemoglobin levels and total cholesterol levels were low. In addition, the patients in the $\mathrm{RDW} \geq 12.2$ group had high usage of $\beta$-blockers in the hospital. Multivessel coronary artery disease, the proportion of complete revascularization rate and other aspects had no sig- 
nificant difference between the patients in the two groups (Table 1). $\geq 12.2$ before PCI was still an independent predictor of mortality for the patients (HR 2.171, 95\% CI 1.007, 4.680, $p=$ 0.048 , Table 2).

Table 1: General data

\begin{tabular}{|c|c|c|c|}
\hline & RDW $<12.2$ & RDW $\geq 12.2$ & \\
\hline & 1170 & 1015 & $p$ \\
\hline Female, n (\%) & $282(24.1)$ & $320(31.5)$ & $<0.001$ \\
\hline Age (years old) & $59.2 \pm 10.2$ & $61.6 \pm 10.6$ & 0.498 \\
\hline Admission BMI $\left(\mathrm{Kg} / \mathrm{m}^{2}\right)$ & $25.7 \pm 3.0$ & $26.0 \pm 3.2$ & 0.043 \\
\hline \multicolumn{4}{|l|}{ Medical history } \\
\hline Hypertension, $\mathrm{n}(\%)$ & $743(63.5)$ & $704(69.4)$ & 0.004 \\
\hline Diabetes mellitus, $\mathrm{n}(\%)$ & $296(25.3)$ & $276(27.2)$ & 0.315 \\
\hline A history of cerebrovascular disease, $\mathrm{n}(\%)$ & $79(6.8)$ & $98(9.7)$ & 0.013 \\
\hline Old history of myocardial infarction, $\mathrm{n}(\%)$ & $235(20.1)$ & $238(23.4)$ & 0.057 \\
\hline Current smoking history, $\mathrm{n}(\%)$ & $410(35.0)$ & $377(37.1)$ & 0.308 \\
\hline A family history of premature coronary heart disease, $\mathrm{n}(\%)$ & $71(6.1)$ & $51(5.0)$ & 0.322 \\
\hline Previous PCI history, $\mathrm{n}(\%)$ & $121(10.3)$ & $122(12.0)$ & 0.213 \\
\hline \multicolumn{3}{|l|}{ Diagnosis } & 0.262 \\
\hline NSTEMI & $108(9.2)$ & $80(7.9)$ & \\
\hline UA & $1062(90.8)$ & $935(92.1)$ & \\
\hline Systolic pressure (mmHg) & $130.9 \pm 19.1$ & $132.5 \pm 20.1$ & 0.073 \\
\hline Diastolic pressure $(\mathrm{mmHg})$ & $79.3 \pm 10.9$ & $79.4 \pm 10.8$ & 0.674 \\
\hline Left ventricular ejection fraction (\%) & $62.7 \pm 10.1$ & $61.6 \pm 10.4$ & 0.295 \\
\hline WBC $\left(10^{9} / \mathrm{L}\right)$ & $7.1 \pm 2.0$ & $7.1 \pm 2.0$ & 0.957 \\
\hline Haemoglobin $(\mathrm{g} / \mathrm{dL})$ & $14.0 \pm 1.5$ & $13.6 \pm 1.6$ & 0.008 \\
\hline $\operatorname{GFR}\left(\mathrm{ml} \cdot \mathrm{min}^{-1} \cdot 1.73 \mathrm{~m}^{-2}\right)$ & $86.9 \pm 24.3$ & $83.2 \pm 27.6$ & 0.262 \\
\hline Total cholesterol (mg/dL) & $183.6 \pm 45.0$ & $179.2 \pm 42.9$ & 0.042 \\
\hline $\mathrm{C}-\mathrm{LDL}(\mathrm{mg} / \mathrm{dL})$ & $103.1 \pm 33.1$ & $105.7 \pm 34.2$ & 0.129 \\
\hline Triglyceride (mg/dL) & $165.1 \pm 111.5$ & $165.7 \pm 107.7$ & 0.798 \\
\hline $\mathrm{HDL}(\mathrm{mg} / \mathrm{dL})$ & $40.6 \pm 8.9$ & $41.6 \pm 9.4$ & 0.091 \\
\hline Blood sugar (mg/dL) & $107.6 .1 \pm 36.4$ & $107.8 \pm 36.7$ & 0.730 \\
\hline \multicolumn{4}{|l|}{ Drug therapy during hospitalization } \\
\hline$\beta$ blockers, $\mathrm{n}(\%)$ & $1007(86.1)$ & $904(89.1)$ & 0.035 \\
\hline Aspirin, n (\%) & $1162(99.3)$ & $1005(99.0)$ & 0.437 \\
\hline DAPT n $(\%)$ & $1150(98.3)$ & $990(97.5)$ & 0.216 \\
\hline Statin, $\mathrm{n}(\%)$ & $1004(85.8)$ & $883(87.0)$ & 0.422 \\
\hline $\mathrm{ACEI} / \mathrm{ARB} \mathrm{n}(\%)$ & $708(60.5)$ & $616(60.7)$ & 0.933 \\
\hline Multivessel disease, $\mathrm{n}(\%)$ & $647(55.3)$ & $591(58.3)$ & 0.168 \\
\hline Complete revascularization, $\mathrm{n}(\%)$ & $893(76.3)$ & $741(73.0)$ & 0.075 \\
\hline
\end{tabular}

BMI: body mass index; NSTEMI: non-ST segment elevation acute coronary syndrome; UA: urinalysis; WBC: white blood cell count; GFR: glomerular filtration rate; ACEI/ARB: angiotensin-converting enzyme inhibitor, C-LDL: low-density lipoprotein cholesterol; HDL: high density lipoprotein; DAPT: dual antiplatelet therapy; $\mathrm{ACEI} / \mathrm{ARB}$ : angiotensin-converting enzyme inhibitor

\section{Mortality}

Twenty-seven cases in the RDW $\geq 12.2$ group died after PCI $(2.7 \%)$, which was significantly higher than patients in the RDW $<12.2$ group (12 cases, $1.0 \%, p=0.004$ ). The related risk factors were taken as a continuous independent variable. After adjusting for factors such as: gender, age, admission BMI, hypertension, diabetes, history of cerebrovascular disease, old myocardial infarction, current smoking history, family history of premature coronary heart disease, previous PCI history, systolic blood pressure, diastolic blood pressure, left ventricular ejection fraction, white blood cells, haemoglobin, glomerular filtration rate total cholesterol, LDL, triglycerides, high-density lipoprotein, fasting glucose, numbers of diseased coronary arteries and medication during hospitalization, RDW
Table 2: Risk factors of percutaneous coronary intervention postoperative mortality

\begin{tabular}{llc}
\hline Risk factors & RR (95\% CI) & $\boldsymbol{p}$ \\
\hline Age & $1.063(1.015-1.113)$ & 0.010 \\
Diabetes mellitus & $2.454(1.258-4.7900)$ & 0.008 \\
GFR & $0.974(0.956-0.992)$ & 0.005 \\
Lesion vessel number & $1.829(1.145-2.923)$ & 0.012 \\
WBC & $1.155(1.005-1.327)$ & 0.042 \\
RDW & $2.171(1.007-4.680)$ & 0.048
\end{tabular}

GFR: glomerular filtration rate; WBC: white blood cell range; RDW: Red blood cell distribution width 
Long-term survival of patients in the RDW $\geq 12.2$ group was significantly lower than that of the patients in the RDW $<$ 12.2 group (Fig. 1).

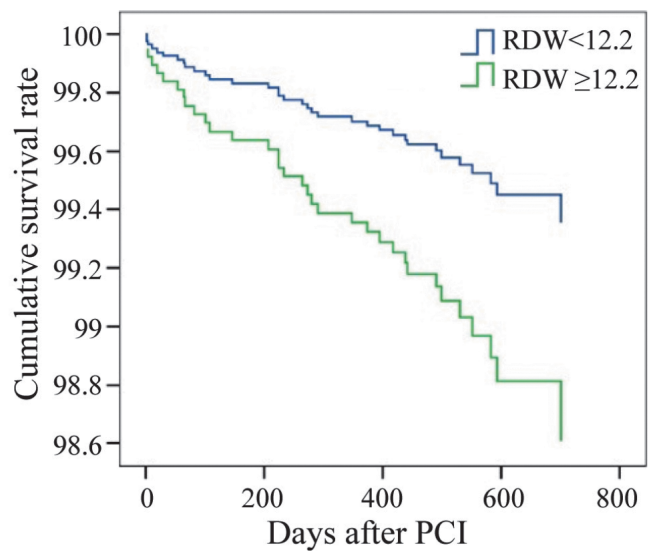

Fig. 1: Effect of red blood cell distribution width on the long-term survival rate.

\section{DISCUSSION}

The results of this study showed that in the NSTEACS patients undergoing PCI, the proportion with both hypertension and cerebrovascular disease for the patients in the $\mathrm{RDW} \geq 12.2$ group was high, and the postoperative mortality was 2.7 times of the patients in the RDW $<12.2$ group. After adjusting for other factors, RDW $\geq 12.2$ of the patients before PCI was an independent predictor of postoperative mortality (HR 2.171, 95\% CI 1.007, 4.680, $(p=0.048)$.

A similar conclusion was also found in the study on the patients with stable coronary artery disease. The study of Osadnik et al (13) included 2550 cases with stable coronary artery disease undergoing PCI; the subjects were divided into four groups according to the RDW level before grouping. After 2.5 years of follow-up, it was found that the mortality of the highest RDW group ( $\geq 14.1 \%$ ) was four times $(17.1 \%$ vs $4.3 \%$, $p$ $<0.0001)$ of that of the lowest group $(<13.1 \%)$. Tsuboi et al (14) studied 560 cases with stable coronary artery disease with diabetes mellitus undergoing PCI, and it was found in the 3.9 years of follow-up that the death rate of the increased value RDW group $(13.3 \%, 14.2 \%)$ was 2.56 times $(95 \%$ CI of 1.12 , $6.62, p=0.025)$ of that in the low-value RDW group $(12.4 \%$, $12.9 \%)$.

Increased RDW may be the overall performance of various potential adverse factors; RDW prognostic effect on cardiovascular disease may also be a variety of factors prognostic role on the external manifestation of cardiovascular disease. The exact mechanism of RDW related to the prognosis of cardiovascular disease was not clear. Studies have shown that elevated neutral/lymphocyte ratio was considered as an indicator directly reflecting inflammation, which had a high degree of correlation with the level of RDW, so RDW was considered as an inflammatory cytokine (2). As a classic inflammatory cytokines, IL-6 Interleukin-6 was closely linked with elevated RDW (3). Interleukin-6 was a potent inducer for hepcidin gene transcription, whose increase can lead to a lack of iron, thereby increasing RDW (15). Interleukin-6 was a multifunctional cytokine and had an important role in the vascular injury of coronary heart disease, which had become an important marker of coronary atherosclerotic plaque stability. Interleukin-6 enhanced reactive protein and fibrinogen expression mainly through promoting platelet aggregation, as well as is involved in the inflammatory processes of plaque instability through adjusting the expression of other inflammatory factors (16). Data analysis from the study of Third National Health and Nutrition Survey of the USA showed that C-reactive protein and fibrinogen levels were closely related to white blood cell count (WBC) and elevated RDW (17). Lippi et al (4) found that the relationship between high RDW and elevated inflammatory markers was similar to the association between the erythrocyte sedimentation rate and C-reactive associated protein, and this relationship was independent of its concomitant diseases. After excluding the blood diseases, this relationship was also present. C-reactive protein is an independent risk factor for coronary artery disease, the elevated levels of C-reactive protein was positively correlated with the incidence of cardiovascular adverse events (18-20). Therefore, the prediction of RDW on cardiovascular disease prognosis may reflect the prognosis of inflammation on cardiovascular disease.

The study was a single-center retrospective study. The presence of residual confounding factors may affect the results, in addition to the lack of serum iron, folic acid, vitamin B12 other indicators.

Accurate risk stratification and prognosis assessment were performed to patients with coronary artery disease to identify the high-risk groups, which was essential for clinicians. The detection for RDW was simple and easy without additional costs, so it has the potential to become a new indicator in the prognostic evaluation and risk stratification of the patients with coronary artery disease.

\section{AUTHORS' NOTE}

All authors have no conflict of interest regarding this paper.

\section{REFERENCES}

1. Lin CK, Lin JS, Chen SY, Chen SY, Jiang ML, Chiu CF. Comparison of hemoglobin and red blood cell distribution width in the differential diagnosis of microcytic anemia. Arch Pathol Lab Med 1992; 116: 1030-2.

2. Akin F, Köse N, Ayça B, Katkat F, Duran M, Uysal OK et al. Relation between red cell distribution width and severity of coronary artery disease in patients with acute myocardial infarction. Angioloy 2013; 64: 592-6.

3. Allen LA, Felker GM, Mehra MR, Chiong JR, Dunlap SH, Ghali JK et al. Validation and potential mechanisms of red cell distribution width as a prognostic marker in heart failure. J Card Fail 2010; 16: 230-8.

4. Lippi G, Targher G, Montagnana M, Salvagno GL, Zoppini G, Guidi GC. Relation between red blood cell distribution width and inflammatory biomarkers in a large cohort of unselected outpatients. Arch Pathol Lab Med 2009; 133: 628-32.

5. Ferrucci L, Guralnik JM, Woodman RC, Bandinelli S, Lauretani F, Corsi $\mathrm{AM}$ et al. Proinflammatory state and circulating erythropoietin in persons with and without anemia. Am J Med 2005; 118: 1288.

6. Felker GM, Allen LA, Pocock SJ, Shaw LK, McMurray JJ, Pfeffer MA et al. Red cell distribution width as a novel prognostic marker in heart 
failure: data from the CHARM Program and the Duke Databank. J Am Coll Cardiol 2007; 50: 40-7.

7. Pascual-Figal DA, Bonaque JC, Redondo B, Caro C, Manzano-Fernandez $\mathrm{S}$, Sánchez-Mas J et al. Red blood cell distribution width predicts longterm outcome regardless of anaemia status in acute heart failure patients. Eur J Heart Fail 2009; 11: 840-6.

8. Tonelli M, Sacks F, Arnold M, Moye L, Davis B, Pfeffer M et al. Relation between red blood cell distribution width and cardiovascular event rate in people with coronary disease. Circulation 2008; 117: 163-8.

9. Dabbah S, Hammerman H, Markiewicz W, Aronson D. Relation between red cell distribution width and clinical outcomes after acute myocardial infarction. Am J Cardiol 2010; 105: 312-7.

10. Nabais S, Losa N, Gaspar A, Rocha S, Costa J, Azevedo P et al. Association between red blood cell distribution width and outcomes at six months in patients with acute coronary syndromes. Rev Port Cardiol 2009; 28: 905-24.

11. Rhodes CJ, Wharton J, Howard LS, Gibbs JS, Wilkins MR. Red cell distribution width outperforms other potential circulating biomarkers in predicting survival in idiopathic pulmonary arterial hypertension. Heart 2011; 97: $1054-60$.

12. Hampole CV, Mehrotra AK, Thenappan T, Gomberg-Maitland M, Shah SJ. Usefulness of red cell distribution width as a prognostic marker in pulmonary hypertension. Am J Cardiol 2009; 104: 868-72.

13. Osadnik T, Strzelczyk J, Hawranek M, Lekston A, Wasilewski J, Kurek A et al. Red cell distribution width is associated with long-term prognosis in patients with stable coronary artery disease. BMC Cardiovasc Disord 2013; 13: 113 .
14. Tsuboi S, Miyauchi K, Kasai T, Ogita M, Dohi T, Miyazaki T et al. Impact of red blood cell distribution width on long-term mortality in diabetic patients after percutaneous coronary intervention. Cir J 2013; 77: 456-61.

15. Lee P, Peng H, Gellbart T, Wang L, Beutler E. Regulation of hepcidin transcription by interleukin-1 and interleukin-6. Proc Natl Acad Sci USA 2005; 102: 1906-10.

16. Schieffer B, Schieffer E, Hilfiker-Kleiner D, Hilfiker A, Kovanen PT, Kaartinen $\mathrm{M}$ et al. Expression of angiotensin II and interleukin 6 in human coronary atherosclerotic plaques: potential implications for inflammation and plaque instablility. Circulation 2000; 101: 1372-8.

17. Patel KV, Ferrucci L, Ershler WB, Longo DL, Guralnik JM. Red blood cell distribution width and the risk of death in middle-aged and older adults. Arch Intern Med 2009; 169: 515-23.

18. Ma FL, Li S, Li XL, Liu J, Qing P, Guo YL et al. Correlation of red cell distribution width with the severity of coronary artery disease: a large Chinese cohort study from a single center. Chin Med J (Engl) 2013; 126: $1053-7$.

19. Veeranna V, Zalawadiya SK, Panaich S, Patel KV, Afonso L. Comparative analysis of red cell distribution width and high sensitivity C-reactive protein for coronary heart disease mortality prediction in multi-ethnic population: findings from the 1999-2004 NHANES. Int J Cardiol 2013; 168: $5156-61$

20. Isik T, Kurt M, Ayhan E, Uyarel H, Tanboga IH, Korkmaz AF et al. Relation of red cell distribution width with presence and severity of coronary artery ectasia. Clin Appl Thromb Hemost 2012; 18: 441-7. 